\title{
FINANCIAL LITERACY AND INVESTMENT DECISION: THE CASE OF SALARIED FEMALES
}

\author{
Ravneet Kaur*
}

Research Scholar, Department of Management Studies, RIMT University, Punjab, India

\section{Dr. Rajiv Kumar Maheshwary}

Professor cum Dean, School of Management and Commerce, RIMT University, Punjab, India

*Corresponding Author

\begin{abstract}
With manifold increase in complexities in the financial environment globally coupled with the enhanced availability of products and services have brought alongside significant risks too. It has therefore become imperative for every nation be developed or developing to make its population aware about not only the financial products/services available but also the concepts on which they are based and the intricacies involved thus making them financially literate. Financial literacy has become all the essential for females for they have been regarded as quite vulnerable when it comes to financial matters. The present study encompasses the evaluation of financial literacy with regard to salaried females alongside evaluation its impact on the considerations affecting their investment decisions. The data has been collected using a questionnaire from the 100 salaried females in Ludhiana city. The data has been analyzed using chi-square tests, factor analysis and regression analysis. The overall score for financial literacy has been 59.53 percent being lower than the benchmark OECD (2020) score of 60.48 percent. Regression analysis pointed out the significant of the financial literacy levels on the considerations affecting the investment decision of the respondents. Other key findings included the significant association of socioeconomic demographics variables. The paper contributes to the field by helping understand the intricacies in relation to the female's financial literacy and its implications for investment decision making.
\end{abstract}

Key words: Financial Literacy, Investment Decision, Individuals, Salaried Females, Socio-Economic, Demographics.

Cite this Article: Ravneet Kaur and Rajiv Kumar Maheshwary, Financial Literacy and Investment Decision: The Case of Salaried Females, International Journal of Management (IJM), 11(6), 2020, pp. 2222-2233.

https://iaeme.com/Home/issue/IJM?Volume=11\&Issue $=6$ 


\section{INTRODUCTION}

The current scenario of the financial world has required individuals to be adequately informed and skilled in managing their finances adequately. This is attributable to the fact that developments in the financial markets have culminated in the emergence of a wide variety of financial products and services, this, in turn, has intensified the scope of complexity. Quick access to financial services and credit cards, financial market deregulation, and technological advances have encouraged individuals by offering different alternatives, but have also raised the likelihood of entering the debt trap. So, its significant for the individuals to be aware of the intricacies associated with these to take full advantage of the available options and safeguard themselves from unnecessary risk i.e., be financially literate. Various academic researchers have empirically shown that individuals with less financial knowledge or literacy struggle to prepare for retirement (Lusardi \& Mitchell, 2007a), invest in the stock market (Lusardi \& Mitchell, 2007a), and risk ending up borrowing at higher interest rates (Stango \& Zinman, 2006). OECD defines financial literacy as "combination of awareness, knowledge, skill, attitude and Behaviour necessary to make sound financial decisions and ultimately achieve individual financial wellbeing." (OECD INFE, 2014).

For vulnerable groups, such as women, financial literacy has become even more critical. This had been illustrated multiple times that women are three times more likely than men to admit they probably couldn't afford to save enough for retirement and have significantly lower financial literacy levels, while also being three times more probable to leave their jobs to care for a member of the family. It has been commonly noted that females earn less, save less, and live longer so therefore it all the more important for them to be financially independent also not only presently but in future also. Recognizing the opportunities to boost earnings and make better use of the opportunities available will enable women to make the most out of their earnings and make an investment that ideally matches their needs and ambitions to create a safer financial future for them. Research has also argued the role of demographics in assessing the financial literacy levels of the individuals. Social influences, family variables, household financial situation, college-educated parents are discovered to impact financial literacy as per Lusardi et al. (2010). Besides, older individuals and having qualified parents have higher financial literacy.

\section{OBJECTIVES OF THE STUDY}

- To evaluate the level of financial literacy among salaried females in Ludhiana city.

- To assess the impact of level of financial literacy on the considerations affecting the investment decision among salaried females in Ludhiana city.

- To associate socio-economic demographics with the financial literacy levels among salaried females in Ludhiana city.

\section{LITERATURE REVIEW}

Klatt (2009) conducted a study assessing the financial literacy of females aged 16 years and above to identify barriers that prevent knowledge and understanding translate into actual behaviour. The study found that some barriers hamper female's participation in financial matters also education plays an important role in females' financial literacy. So therefore, specific programs, workshops targeting the enhancement of their knowledge alongside giving due importance to inculcate financial education at home also should be ensured. Silva, Silva and Bhuptani (2012) highlighting the importance of financial literacy to achieve the goal of 
financial inclusion in the economy, the study aimed at assessing the financial literacy levels among females. The study concluded that although females do have some degree of financial security still, they are not financially literate. Moreover, urban area females do enjoy financial freedom in taking decisions both personally and for a family as a whole but the majority are ignorant about different investment opportunities available. Aren and Zengin (2016) investigated the variables affecting investment preferences and found that there is no relation between personality trait and choice of investment whereas risk perception and level of financial literacy do impact individuals' investment preference. Also, the study concluded there exists a significant relationship between financial literacy and investment preferences. It showed that respondents with lower financial literacy levels opted deposit and foreign currency and those with high financial literacy tend to create portfolio or purchase equity. Moreover, basic financial literacy levels had no relation with gender. Lusardi and Mitchell (2008) raised concerns about the ability of females to make sound saving and investment decisions. Their study found a low level of financial literacy among older females in the US, with the majority of females not doing anything for retirement planning. Moreover, it was concluded that females with higher financial literacy levels are likely to be successful in planning their finances. They found that it is indispensable for females to be financially literate. Additionally, Poongodi \& Gowri (2016) pointed that the working females in general earn, spend and save enough money for their future security and financial needs. These females can be better financial decision makers, if they avoid delay in choosing their right saving/investment avenues. Before beginning an investment portfolio, women should also make a self-evaluation, through continuous reading and watching the activity of the financial and capital market, their literacy levels would certainly be increased. Bhabha et al (2014) assessed financial literacy of working females and its impact on saving- investment behaviour and found that in terms of basic financial literacy aspects, the respondents fair well but, in terms of advanced financial literacy the respondents perform poorly. Koenen et al (2014) the study found that females are less likely to answer the questions on financial literacy and moreover the females themselves gave lower scores on selfassessment financial literacy questions. The research also highlighted that even females with favorable economic conditions and from the vulnerable group i.e., single females and widows both were found to be less financially knowledgeable. The study concluded that it is of paramount importance that females should be financially literate as it will lead to their positive economic behaviour and promote financial security.

\section{RESEARCH MODEL}




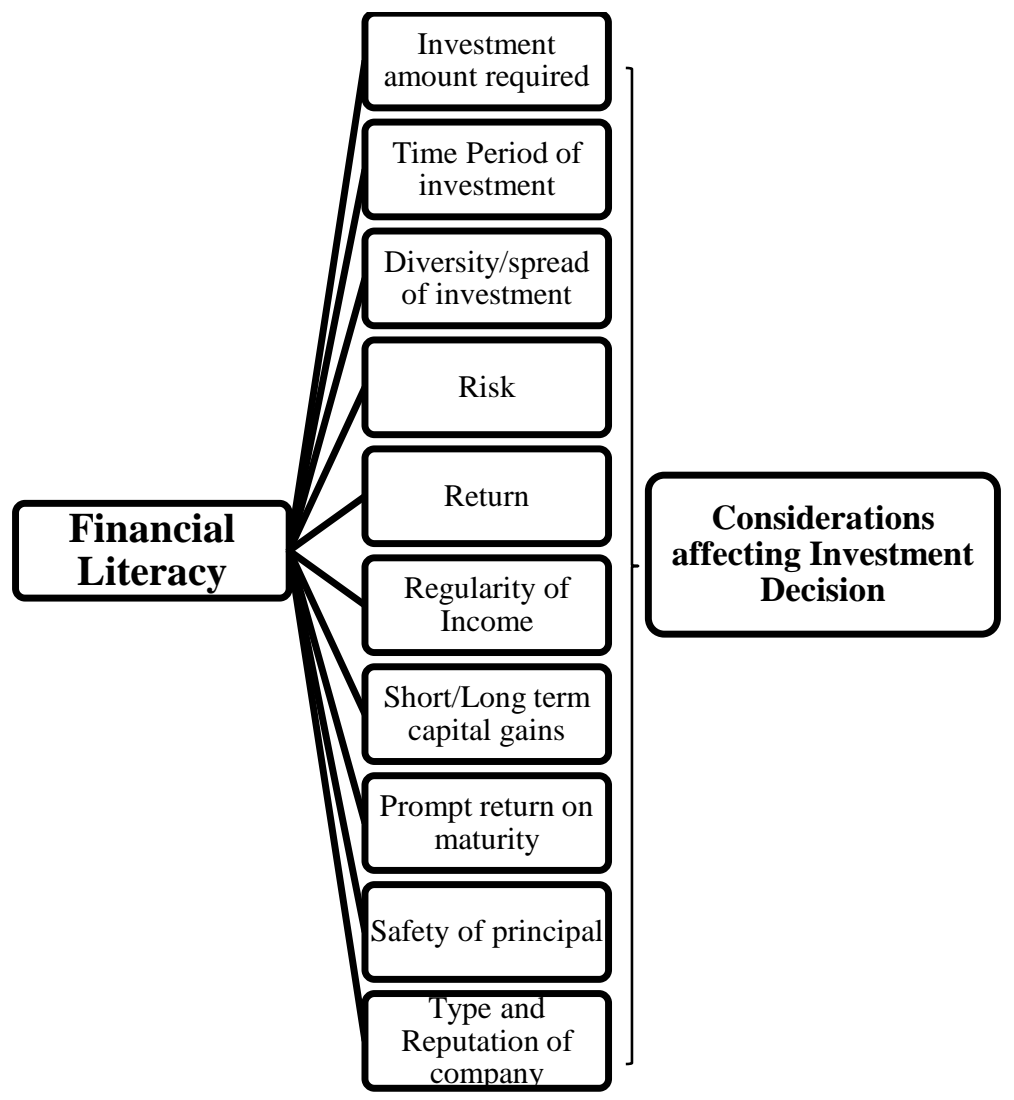

Figure 1 Research Model

\section{RESEARCH METHODOLOGY}

The study uses questionnaire for measuring the financial literacy levels among salaried females. Apart from core questions relating financial aspects and investment decision considerations, information relating to various socio-economic demographics was also collected. Secondary data is collected from various journals, magazines, newspapers etc.

Sampling: The sample size consist of 100 salaried females of Ludhiana city

For each correct answer for financial question one mark is given while for a wrong/don't know is not given any mark i.e., zero mark. The responses for the investment decision considerations has been mapped on the scale of importance with 5- most important to 1- least important. The scores on ten items are then averaged.

\subsection{Data Analysis}

The data is analysed using Chi-Square tests, correlation, factor analysis and linear regression analyses. Linear regression analysis has been employed in this study to examine the impact of financial literacy on the investment decision considerations, where the financial literacy levels have been taken as Independent variable and the factors identified through factor analysis as representing considerations affecting the investment decision as dependent variables. Whereas One-way ANOVA has been employed to see analyse the association of various socio-economic demographics with the financial literacy levels. 


\section{RESULTS AND DISCUSSION}

\subsection{Socio-Economic Demographic Profile}

Table 1 Socio-Economic Demographic profile of Respondents

\begin{tabular}{|c|c|c|c|}
\hline Variable & Description & Frequency & Percentages \\
\hline \multirow{5}{*}{ Age Group } & $21-25$ years & 10 & $10 \%$ \\
\hline & $26-30$ years & 20 & $20 \%$ \\
\hline & $31-35$ years & 36 & $36 \%$ \\
\hline & $36-40$ years & 20 & $20 \%$ \\
\hline & $41-45$ years & 14 & $14 \%$ \\
\hline \multirow{4}{*}{ Family Life Stage } & Single & 34 & $34 \%$ \\
\hline & Young Married without Children & 8 & $8 \%$ \\
\hline & Young Married with Children & 32 & $32 \%$ \\
\hline & Middle aged Married with Children & 26 & $26 \%$ \\
\hline \multirow{4}{*}{$\begin{array}{c}\text { Academic } \\
\text { Qualifications }\end{array}$} & Diploma & 4 & $4 \%$ \\
\hline & Under Graduation & 12 & $12 \%$ \\
\hline & Post-Graduation & 78 & $78 \%$ \\
\hline & Doctoral & 6 & $6 \%$ \\
\hline \multirow{5}{*}{$\begin{array}{l}\text { Occupational } \\
\text { Sector }\end{array}$} & Education & 52 & $52 \%$ \\
\hline & Banking & 22 & $22 \%$ \\
\hline & Corporate & 16 & $16 \%$ \\
\hline & Legal & 2 & $2 \%$ \\
\hline & Others & 8 & $8 \%$ \\
\hline \multirow{2}{*}{ Work Profile } & Finance Related & 50 & $50 \%$ \\
\hline & Non-Finance Related & 50 & $50 \%$ \\
\hline \multirow{4}{*}{$\begin{array}{l}\text { Total Work } \\
\text { Experience }\end{array}$} & Less than $5 \mathrm{yrs}$ & 32 & $32 \%$ \\
\hline & 6-10 yrs & 36 & $36 \%$ \\
\hline & $11-15 \mathrm{yrs}$ & 22 & $22 \%$ \\
\hline & More than 15 yrs & 10 & $10 \%$ \\
\hline \multirow{5}{*}{ Monthly Income } & Up to ₹ 10000 & 10 & $10 \%$ \\
\hline & $₹ 10001-20000$ & 24 & $24 \%$ \\
\hline & ₹ 20001-30000 & 18 & $18 \%$ \\
\hline & ₹ 30001-40000 & 22 & $22 \%$ \\
\hline & Above ₹ 40000 & 26 & $26 \%$ \\
\hline \multirow{4}{*}{$\begin{array}{l}\text { Earning members in } \\
\text { family }\end{array}$} & 1 & 2 & $2 \%$ \\
\hline & 2 & 62 & $62 \%$ \\
\hline & 3 & 20 & $20 \%$ \\
\hline & More than 3 & 16 & $16 \%$ \\
\hline \multirow{3}{*}{ Residential House Status } & Own House & 84 & $84 \%$ \\
\hline & Rented House & 14 & $14 \%$ \\
\hline & Org. provided accommodation & 2 & $2 \%$ \\
\hline \multirow{2}{*}{ Tax Payment } & Yes & 78 & $78 \%$ \\
\hline & No & 22 & $22 \%$ \\
\hline
\end{tabular}

The socio-economic demographic profile of the respondents have been displayed in Table 1. The respondents from the age group 31-35 years have dominated with 36 percent followed by 20 percent each from those from 26-30 years and 36-40 years age group and 14 percent from 41-45 years and 10 percent from 21-25 years age group. The respondents from single category dominated the sample with 34 percent followed by 32 percent from young married with children category, 26 percent from middle aged with children and 8 percent from young married without children category. The post graduate respondents constituted 78 percent of the sample followed by 12 percent under graduates, 6 percent doctorates and 4 percent diploma holders. In terms of occupational sector 52 percent are from education, 22 percent from banking, 16 percent from corporate, 2 percent from legal and 8 percent from others sector respectively. The respondents with more than 15 years total work experience constituted 10 percent, 22 percent had 11-15 
years' work experience, 36 percent had 6-10 years' work experience and 32 percent had less than 5 years' work experience. The income distribution of the sample showed that 26 percent of the respondents earned above ₹40000, 24 percent earned ₹10001-20000, 22 percent earned ₹30001-40000, 18 percent earned ₹20001-30000 and 10 percent earned up to ₹10000 monthly. In terms of the residential house status of the respondent's 84 percent have been living in their own house, 14 percent in rented house and only 2 percent in organisation provided accommodation. 78 percent of the respondents paid tax while 22 percent did not pay tax.

\subsection{Reliability of Instrument}

Table 2 Reliability Statistics

\begin{tabular}{|c|c|c|}
\hline Items & Cronbach's Alpha & N of Items \\
\hline Financial Literacy & .789 & 30 \\
\hline Investment Decision considerations & .893 & 10 \\
\hline
\end{tabular}

The reliability of the instruments used for measuring the financial literacy of the respondents and mapping the considerations for investment decision has been done through calculation of Cronbach Alpha coefficient. An alpha of value greater than 0.7 is regarded as acceptable (Hair et al., 2018). The results for the reliability has been displayed in Table 2. The Cronbach Alpha value for the financial literacy measurement scale has been $\alpha=0.789$ while the same for investment decision considerations has been $\alpha=0.893$, so both the values being above the acceptable value justifying the reliability for the study.

\subsection{Financial Literacy}

Descriptive Analysis ( $\mathrm{N}=100)$

Table 3 Descriptive Statistics

\begin{tabular}{|l|c|}
\hline \multicolumn{2}{|c|}{ Financial Literacy Score } \\
\hline Mean & 17.86 \\
\hline Median & 18.00 \\
\hline Mode & $17^{\text {a }}$ \\
\hline Std. Deviation & 5.199 \\
\hline Minimum & 5 \\
\hline Maximum & 29 \\
\hline
\end{tabular}

Through descriptive analysis for the financial literacy score has been displayed in Table 3. As seen the average overall score of the respondents have been 17.86 (out of 30) i.e., 59.53 percent. The median score have been used to further segregate the respondents into subgroups i.e., those scoring above median i.e., 60 percent has been categorized as the respondents with high financial literacy levels, those scoring equal to median score as ones with moderate financial literacy levels and finally the respondents scoring below median as ones with low financial literacy levels. 


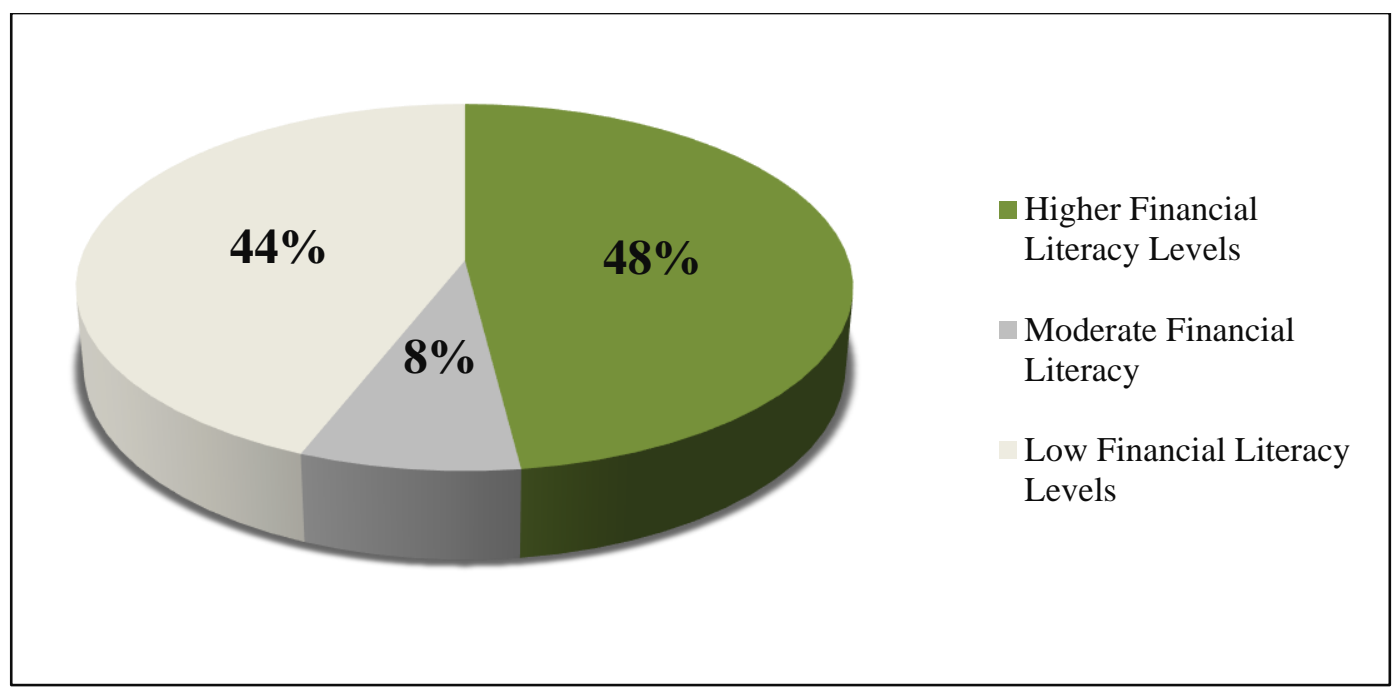

Figure 1 Financial Literacy levels

As evident from Fig. 1 it is clear that 48 percent of the respondents possessed high financial literacy levels while 44 percent possessed low financial literacy levels and 8 percent possessed moderate financial literacy levels. It is evident that a greater number of respondents are found to exhibit higher financial literacy levels.

\subsection{Investment Decision}

The study enumerated various investment decisions considerations and evaluated these on the basis of the importance attributed to these by the respondents by employing Likert 5-point rating scale. These include considerations such as investment amount required, time period of investment, diversity/spread of investment, risk, return, prompt return on maturity, short/long term capital gains etc.

\subsection{Financial Literacy and Investment Decision Considerations Hypothesis}

$\mathrm{H}_{0}$ : There lies no significant impact of financial literacy levels on the considerations affecting the investment decision of the respondents.

$\mathrm{H}_{1}$ : There lies significant impact of financial literacy levels on the considerations affecting the investment decision of the respondents.

The analysis of the influence of the levels of financial literacy on the considerations influencing the respondents' investment decisions is carried out through linear regression, which involves taking the level of financial literacy as an independent variable and the factors (as representing considerations affecting the investment decision) identified through factor analysis as dependent variables.

\section{Factor Analysis}

The KMO value as outlined in Table 4 has been 0.821 while the Bartlett's test showed the significant value of 0.000 justified the application of factor analysis.

Table 4 KMO and Bartlett's Test

\begin{tabular}{|l|l|l|}
\hline \multicolumn{2}{|l|}{ Kaiser-Meyer-Olkin Measure of Sampling Adequacy. } &. $\mathbf{8 2 1}$ \\
\hline \multirow{3}{*}{ Bartlett's Test of Sphericity } & Approx. Chi-Square & 549.719 \\
\cline { 2 - 3 } & df & 45 \\
\cline { 2 - 3 } & Sig. & $\mathbf{. 0 0 0}$ \\
\hline
\end{tabular}


Table 5 represented the factors identified as representing the considerations affecting investment decision of the respondents. In total as per the acceptable factor loadings (greater than 0.5 , Hair et al 2018), two factors have been identified and named accordingly.

Table 5 Rotated Component Matrix ${ }^{\mathrm{a}}$

\begin{tabular}{|c|c|c|c|}
\hline \multirow{2}{*}{ Factors } & \multirow{2}{*}{ Components } & \multicolumn{2}{|c|}{ Component } \\
\hline & & 1 & 2 \\
\hline \multirow{7}{*}{$\begin{array}{l}\text { Factor } 1 \\
\text { Accounting and Financial }\end{array}$} & Type and Reputation of Company & .861 & \\
\hline & Short/Long term capital gains & .799 & \\
\hline & Time Period of investment & .791 & \\
\hline & Return & .703 & \\
\hline & Investment amount required & .637 & \\
\hline & Diversity/spread of investment & .589 & \\
\hline & Risk & .553 & \\
\hline \multirow{3}{*}{$\begin{array}{c}\text { Factor } 2 \\
\text { Personal Financial Needs }\end{array}$} & Regularity of Income & & .872 \\
\hline & Prompt return on Maturity & & .811 \\
\hline & Safety of Principal & & .639 \\
\hline $\begin{array}{l}\text { Extraction Method: Principal C } \\
\text { Kaiser Normalization. }\end{array}$ & nponent Analysis. & \multicolumn{2}{|c|}{ Rotation Method: Varimax wit } \\
\hline
\end{tabular}

\subsection{Correlation and Regression Analysis}

Using Pearson's correlation coefficient, correlation analysis between the variables has been computed. Table 6 displays the results. The results demonstrate that all of the respondents' financial literacy levels were positively and statistically significantly correlated with all the factors and the overall sum of investment considerations impacting the respondents' investment decisions.

Table 6 Correlation Analysis

\begin{tabular}{|c|c|c|c|c|c|}
\hline & & $\begin{array}{c}\text { Financial } \\
\text { Literacy } \\
\text { Level }\end{array}$ & $\begin{array}{c}\text { Factor 1 } \\
\text { Accounting \& } \\
\text { Financial }\end{array}$ & $\begin{array}{c}\text { Factor } 2 \\
\text { Personal } \\
\text { Financial } \\
\text { Need }\end{array}$ & $\begin{array}{c}\text { Overall } \\
\text { Investment } \\
\text { Decision } \\
\text { considerations }\end{array}$ \\
\hline \multirow{3}{*}{$\begin{array}{c}\text { Financial Literacy } \\
\text { Level }\end{array}$} & Pearson Correlation & 1 & $.325^{* *}$ & $.224^{*}$ & $.321^{* * *}$ \\
\hline & Sig. (2-tailed) & & .001 & .025 & .001 \\
\hline & $\mathrm{N}$ & 100 & 100 & 100 & 100 \\
\hline \multirow{3}{*}{$\begin{array}{c}\text { Factor 1 } \\
\text { Accounting \& } \\
\text { Financial }\end{array}$} & Pearson Correlation & $.325^{* *}$ & 1 & $.603^{* *}$ & $.959^{* *}$ \\
\hline & Sig. (2-tailed) & .001 & & .000 & .000 \\
\hline & $\mathrm{N}$ & 100 & 100 & 100 & 100 \\
\hline \multirow{3}{*}{$\begin{array}{c}\text { Factor } 2 \\
\text { Personal Financia } \\
\text { Need }\end{array}$} & Pearson Correlation & $.224^{*}$ & $.603^{* *}$ & 1 & .806 ** \\
\hline & Sig. (2-tailed) & .025 & .000 & & .000 \\
\hline & $\mathrm{N}$ & 100 & 100 & 100 & 100 \\
\hline \multirow{3}{*}{$\begin{array}{c}\text { Overall } \\
\text { Investment } \\
\text { Decision } \\
\text { considerations }\end{array}$} & Pearson Correlation & $.321^{* * *}$ & $.959^{* * *}$ & $.806^{* * *}$ & 1 \\
\hline & Sig. (2-tailed) & .001 & .000 & .000 & \\
\hline & $\mathrm{N}$ & 100 & 100 & 100 & 100 \\
\hline
\end{tabular}

**.Significant at the 0.01 level (2-tailed).

*. Significant at the 0.05 level (2-tailed). 
Table 7 Regression Analysis

\begin{tabular}{|c|c|c|c|c|c|c|c|c|c|c|}
\hline \multirow{2}{*}{ Factors } & \multicolumn{2}{|c|}{\begin{tabular}{|c|} 
Unstandardized \\
Coefficients \\
\end{tabular}} & \multirow{2}{*}{$\mathbf{R}^{2}$} & \multirow{2}{*}{$\underset{\mathbf{R}^{2}}{\text { Adj. }}$} & \multirow{2}{*}{$\begin{array}{l}\text { Std. Error } \\
\text { of estimate }\end{array}$} & \multirow{2}{*}{ Beta } & \multirow{2}{*}{$\begin{array}{l}\text { t-test } \\
\text { value }\end{array}$} & \multirow{2}{*}{ Sig. } & \multirow{2}{*}{ F-test } & \multirow{2}{*}{ Sig. } \\
\hline & B & $\begin{array}{l}\text { Std. } \\
\text { Error }\end{array}$ & & & & & & & & \\
\hline $\begin{array}{l}\text { Accounting and } \\
\text { Financial }\end{array}$ & 3.564 & .232 & \multirow{2}{*}{.105} & \multirow{2}{*}{.096} & \multirow{2}{*}{.644} & \multirow{2}{*}{.325} & \multirow{2}{*}{3.399} & \multirow{2}{*}{.001} & \multirow{2}{*}{11.554} & \multirow{2}{*}{.001} \\
\hline $\begin{array}{l}\text { Financial Literacy } \\
\text { Level }\end{array}$ & 1.271 & .374 & & & & & & & & \\
\hline $\begin{array}{l}\text { Personal Financial } \\
\text { Needs }\end{array}$ & 3.815 & .268 & \multirow{2}{*}{.050} & \multirow{2}{*}{.040} & \multirow{2}{*}{.745} & \multirow{2}{*}{.224} & \multirow{2}{*}{2.271} & \multirow{2}{*}{.025} & \multirow{2}{*}{5.160} & \multirow{2}{*}{.025} \\
\hline $\begin{array}{l}\text { Financial Literacy } \\
\text { Level }\end{array}$ & .982 & .432 & & & & & & & & \\
\hline \begin{tabular}{|l|} 
Overall Investment \\
Decision considerations
\end{tabular} & 3.639 & .219 & \multirow{2}{*}{.103} & \multirow{2}{*}{.094} & \multirow{2}{*}{.608} & \multirow{2}{*}{.321} & \multirow{2}{*}{3.357} & \multirow{2}{*}{.001} & \multirow{2}{*}{11.273} & \multirow{2}{*}{.001} \\
\hline $\begin{array}{l}\text { Financial Literacy } \\
\text { Level }\end{array}$ & 1.184 & .353 & & & & & & & & \\
\hline
\end{tabular}

The t-test and F-test value (Table 7) with the significance p-value being less than 0.05 in all the cases showed that financial literacy level of the respondents is significant variable in explaining the variation towards considerations affecting their investment decision. The linear regression equation can be written as:

\section{Overall Investment Decision Considerations $=3.639+1.184$ (Financial Literacy Level)}

The null hypothesis has thus been dismissed, as the significant value at the 5 percent significance level is less than 0.05. It is therefore inferred that the level of financial literacy has a significant impact on the factors influencing the respondents' investment decisions at a 95 percent confidence level.

\subsection{Financial Literacy and Socio-Economic Demographics}

\section{Hypothesis}

$\mathrm{H}_{0}$ : There lies no significant relationship among socio-economic demographics and level of financial literacy.

$\mathrm{H}_{1}$ : There lies significant relationship among socio-economic demographics and level of financial literacy.

As displayed in Table 8, the Chi-Square tests reveal that among all the socio-economic demographic variables, only Family Life Stage, Work Profile and Monthly Income have found to be significantly related to the financial literacy levels of the respondents at 5 percent level of significance with p-value being less than 0.05 . Therefore, the null hypothesis is rejected only in the case of these three socio-economic demographic variables only.

Table 8 Socio-Economic Demographics and Financial Literacy Levels

\begin{tabular}{|c|c|c|c|c|c|c|c|c|c|}
\hline \multirow{7}{*}{ 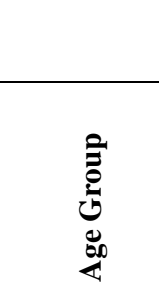 } & \multirow[b]{3}{*}{$21-25 \mathrm{yrs}$} & \multicolumn{6}{|c|}{ Financial Literacy Levels } & \multirow{3}{*}{$\begin{array}{c}\text { Pearson's } \\
\text { Chi-Square }\end{array}$} & \multirow{2}{*}{ Sig. } \\
\hline & & \multicolumn{2}{|c|}{ High } & \multicolumn{2}{|c|}{ Moderate } & \multicolumn{2}{|c|}{ Low } & & \\
\hline & & 6 & $13 \%$ & 0 & $0 \%$ & 4 & $9 \%$ & & \multirow{6}{*}{0.549} \\
\hline & $26-30 \mathrm{yrs}$ & 8 & $17 \%$ & 2 & $25 \%$ & 10 & $23 \%$ & \multirow{5}{*}{6.884} & \\
\hline & $31-35 \mathrm{yrs}$ & 20 & $42 \%$ & 2 & $25 \%$ & 14 & $32 \%$ & & \\
\hline & $36-40 \mathrm{yrs}$ & 6 & $13 \%$ & 2 & $25 \%$ & 12 & $27 \%$ & & \\
\hline & $41-45 \mathrm{yrs}$ & 8 & $17 \%$ & 2 & $25 \%$ & 4 & $9 \%$ & & \\
\hline & Total & 48 & $100 \%$ & 8 & $100 \%$ & 44 & $100 \%$ & & \\
\hline \multirow{2}{*}{ 头葛入气。 } & Single & 20 & $42 \%$ & 0 & $0 \%$ & 14 & $32 \%$ & \multirow{2}{*}{15.926} & \multirow{2}{*}{0.01} \\
\hline & Young married without children & 0 & $0 \%$ & 2 & $25 \%$ & 6 & $14 \%$ & & \\
\hline
\end{tabular}


Financial Literacy and Investment Decision: The Case of Salaried Females

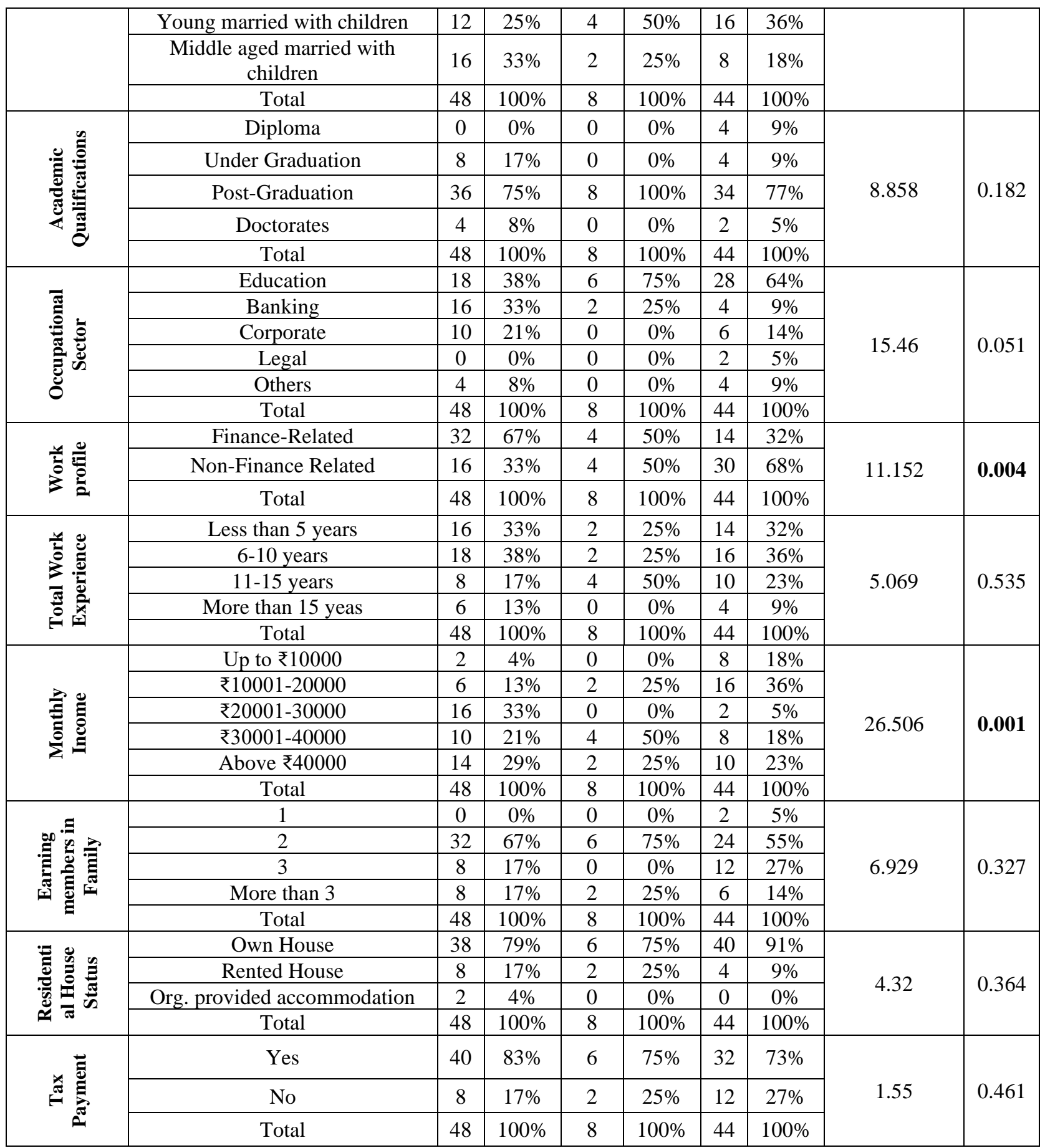

\section{CONCLUSION}

The current scenario globally is being marked by prodigious changes in financial sector with advent of wide array of investment opportunities but these avenues where on one hand are bringing higher returns, on the other also bring along higher degrees of risk and complexity. Thus, it has become imperative for individuals of all age groups alike specifically those belonging to vulnerable group such as females to be aware about the concepts on which these avenues are based, so that one can reap maximum out of them. The present study about the financial literacy levels of salaried females concludes that the overall score of the respondents has been $59.53 \%$ and $48 \%$ of the respondents showed higher levels of financial literacy. Additionally, it was found that financial literacy level had statistically significant positive correlation with and statistically significant impact on considerations impacting the Investment 
Decision. It was found that among all the socio-economic demographics only family life stage, work profile and monthly income were found to be significantly related to the financial literacy levels of the salaried females.

\section{THEORETICAL IMPLICATIONS}

The research aimed at making contribution to the financial literacy literature by assessing the financial literacy of salaried females. Comprehensive approach is applied in the research to assess the levels of financial literacy and its impact on subsequent financial behaviour. The research aims at assisting the policy makers, government, institutions, banks etc. by providing them insights into the financial literacy of salaried females and how they behave financially and make investment decision. This information will help them in devising appropriate policies/products/services specially targeted to females. These concrete targeted initiatives taken can ensure concrete economic empowerment and freedom to the females.

\section{LIMITATIONS AND FUTURE SCOPE}

The study sample is restricted to Ludhiana city salaried females only. The approach adopted for primary data collection has been the method of non-probability convenience sampling, which has its weaknesses, so these are immediately extended to the analysis.

The study can be expanded to include comparison between salaried and non-salaried individuals or urban vs rural areas. At a broad spectrum, the research can also aim at the role of financial literacy on female's empowerment. The study is performed for Ludhiana city only, it can also be conducted in different parts of state or nation.

\section{REFERENCES}

[1] Agarwala, S.K., Barua, S., Jacob, J. and Verma, J. R.(2013), Financial literacy among working young in urban India, Working Paper, IIM-Ahmedabad

[2] Aren, S., and Zengin, A. N. (2016), "Influence of financial literacy and risk perception on choice of investment". Procedia-Social and Behavioural Sciences, Vol. 235, pp 656-663.

[3] Bhabha, J., Khan, S., Qureshi, Q., Naeem, A. and Khan, I., (2014), "Impact of financial literacy on saving-investment behaviour of working females in the developing countries", Research Journal of Finance and Accounting, Vol. 13(5), Pp 118-122.

[4] Hair, J. F., William, B. C., Barry, B. J., Anderson, R. E.\& Tatham, R. L. (2018). Multivariate Data Analysis (6th ed.). New Delhi: Cengage Learning India Pvt. Ltd.

[5] Klatt, M. E. (2009), "An Assessment of Females's Financial Literacy", Available at: http://www2.uwstout.edu/content/lib/thesis/2009/2009klattm.pdf, University of WisconsinStout, United States. Accessed on December 2018.

[6] Koenen, T.B, Lusardi, A., Alessie, R. And Van Rooij, M. (2014), "How financially literate are females? An overview and new insights", NBER Working Paper No. 20793.

[7] Lusardi, A. (2008), "Financial Literacy: An Essential Tool for Informed Consumer Choice?" Working Paper, Joint Center for Housing Studies, Harvard University

[8] Lusardi, A., and Mitchell, O. (2007a), "Financial Literacy and Retirement Preparedness: Evidence and Implications for Financial Education”, Business Economics, Vol. 42 (1), pp 3544. 
Financial Literacy and Investment Decision: The Case of Salaried Females

[9] Lusardi,A., Mitchell,O. S. and Curto,V.(2010), "Financial Literacy and Financial Sophistication among Older Americans”, Journal of Consumer Affairs, Vol. 44(2), pp 358-380.

[10] OECD (2014) “OECD Definition of Financial Literacy” Retrieved from www.oecd.org.

[11] Poongodi and Gowri (2016), “The Financial Literacy and Saving/Investment Behaviour Among Indian Females: With Special References to Erode City". Intercontinental Journal of Finance Research Review, Vol. 4(5).

[12] Silva, B., Silva, S., \& Bhuptani, R. S. (2012), "Assessing the financial literacy level among females in India: An empirical study". Journal of Entrepreneurship and Management, Vol. 1(1), pp 46-52.

[13] Stango, Victor and Jonathan Zinman (2006), "Fuzzy Math and Red Ink: Payment/Interest Bias, Intertemporal Choice and Wealth Accumulation," Working Paper, Dartmouth College. 